\title{
EFFECT OF ORGANIZATIONAL CULTURE INTENSITY ON JOB SATISFACTION
}

\author{
Pengaruh Intensitas Budaya Organisasi terhadap Kepuasan Kerja \\ *Prasiska Ramadyaning Utami ${ }^{1}$, E. Maria Kristine Sitohang ${ }^{2}$ \\ ${ }^{1}$ The Indonesian Public Health Association of East Java Province, Indonesia \\ ${ }^{2}$ Faculty of Public Health, Airlangga University, Indonesia \\ ${ }^{*}$ Correspondence: prasiska.ramadyaning.utami-2015@fkm.unair.ac.id
}

\begin{abstract}
Background: Organizations need to pay attention to the job satisfaction of their members to achieve their goals. In 2011, the Airlangga Healthcare Center surveyed job satisfaction with the target of $80 \%$. However, the target has not been achieved. Job satisfaction can be affected by several factors, and one of them is the culture within the organization.

Aim: This study aims to analyze the effect of organizational culture intensity towards job satisfaction of the Airlangga Healthcare Center's employees.

Method: This study was conducted in November 2011 - June 2012 with a cross-sectional research design. The sample of the study used the population total technique. The independent variable of the research was the organizational culture intensity. While the dependent variable was job satisfaction. The data were analyzed descriptively by employing cross-tabulation analysis between organizational culture intensity and job satisfaction. Results: The most influential aspect of the organizational culture was cooperation that reached $73.9 \%$. Job satisfaction aspects with a very satisfying level were job and co-worker aspects that reached $78.3 \%$. The most influential aspect of organizational cultures that affect job satisfaction is trust that amounted to $83.3 \%$. However, the organizational cultures affect job satisfaction with a percentage of $92.3 \%$ overall.

Conclusion: The research concludes that the organizational culture intensity is a factor that affects job satisfaction of the employees at the Airlangga Healthcare Center. The recommendation for the organization is to improve the togetherness aspect of organizational cultures.
\end{abstract}

Keywords: organizational culture intensity, job satisfaction, organization.

\section{ABSTRAK}

Latar Belakang: Organisasi perlu memperhatikan aspek kepuasan kerja anggotanya untuk mencapai tujuan. Pada tahun 2011 PLK UNAIR melakukan survei terhadap kepuasan kerja karyawan dengan target kepuasan kerja sebesar 80\%, namun target tersebut belum tercapai. Kepuasan kerja dapat dipengaruhi oleh beberapa faktor salah satunya adalah budaya yang ada di dalam organisasi tersebut.

Tujuan: Penelitian ini bertujuan untuk menganalisis pengaruh intensitas budaya organisasi terhadap kepuasan kerja karyawan PLK UNAIR Surabaya.

Metode: Penelitian ini dilakukan pada November 2011 - Juni 2012 dengan desain penelitian cross-sectional. Pengambilan Sampel dalam penelitian ini menggunakan teknik total populasi. Variabel bebas penelitian adalah intensitas budaya organisasi, sedangkan variabel terikat penelitian adalah kepuasan kerja. Data dianalisis secara deskriptif dengan tabulasi silang antara intensitas budaya organisasi dengan kepuasan kerja.

Hasil: Intensitas budaya organisasi kuat yang paling tinggi adalah aspek budaya organisasi kerjasama sebesar 73,9\%. Aspek kepuasan kerja yang memiliki kepuasan sangat puas adalah aspek pekerjaan dan aspek rekan kerja sebesar 78,3\%. Aspek budaya organisasi yang paling kuat mempengaruhi kepuasan adalah kepercayaan sebesar 83,3\%. Tetapi, secara keseluruhan aspek budaya organisasi mempengaruhi kepuasan kerja dengan presentasi sebesar $92,3 \%$.

Kesimpulan: Intensitas budaya organisasi merupakan faktor yang berpengaruh terhadap kepuasan kerja karyawan PLK UNAIR. Rekomendasi untuk pihak organisasi untuk melakukan upaya peningkatan terhadap aspek budaya organisasi kebersamaan.

Kata kunci: intensitas budaya organisasi, kepuasan kerja, organisasi.

\section{INTRODUCTION}

The development of health efforts cannot be separated from the government's roles in improving health facilities. According to the Government Regulation of Republic of Indonesia Number 47 of
2016, healthcare is a place that is used to organize healthcare both promotive, preventive, curative, and rehabilitative that is carried out by the central government, local government, and or society. Healthcare is divided into three stages, i.e., the first 
level of healthcare, the second level of healthcare, and the third level of healthcare.

The Airlangga Healthcare Center Surabaya is the primary level of healthcare located in Airlangga University. It has two clinics that are located in campus $B$ and campus $C$. Its vision is to be a holistic healthcare organizer for the students, staff, and societies by implementing "managed care" to create healthy productive human resources.

The Airlangga Healthcare Center is an organization since it consists of people who have a certain structural organization and work together to achieve the goals relating to the vision and mission that have been determined. Hasibuan (2011) explained that an organization is a formal, structured, and coordinated system of a group of people who work together to achieve the goals. The main characteristics of the organization are summarized as 3P: Purpose, People, and Plan (Novita, Sunuharjo and Ruhana, 2016). An organization must have clear purposes. In the organization, people are one of the factors to reach the organization's goals. Meanwhile, the organization's plan is a strategy, system, design, and structure that is used to motivate people to achieve their goals.

The organization's life cannot be separated from the organizational culture that is adapted to the organization. Schein (2016) explained that:

\section{"Organizational culture is a pattern of shared basic assumptions that a group has learned as it solved its problems of external adaptation and internal integration, that has worked well enough to be considered valid and therefore, to be taught to new members as the correct way to perceive, think, and feel in relation to those problems".}

Therefore, organizational culture is a common pattern of an assumption that is used to solve problems, create employees who can adapt to the environment and embrace the organization's members. Robbins and Judge (2012) explained that the organizational culture is a system of shared meaning that is held by the members, and it will distinguish one organization from other organizations. The organizational culture is often interpreted as the values, symbols owned by the organization and understood and adhered by all members to create an organization different from other organizations (Hakim and Hadipapo, 2015).

The organizational culture in the Airlangga Healthcare Center is based on the basic value of its missions, i.e., the excellent quality service, while the general value is discipline, cooperation, and togetherness, and inter-belief or trust. The five aspects which are also the basic values of organizational culture are expected to be implemented by each member of the organization in providing services to patients. This matter will distinguish the Airlangga Healthcare Center from other health service centers.

The organization's life that is seen from the organizational culture can be separated within the strong and weak organizational cultures (Robbins, 2015). The strength or weakness of organizational cultures can be seen from the members who complete the tasks according to the term and culture's values of the organizations.

The organization that has a strong culture could have a meaningful effect on the member's behaviors. The main value of the organization is held strongly by the members of the strong organization's culture. The strength of the strong organization's culture affects job satisfaction and decreasing numbers of the employee and the whole organization performance (Robbins, 2015). When the established organization's culture suits the employees, there is a great possibility for employees to achieve their job satisfaction.

The job satisfaction is an evaluation of the employees' feelings toward their jobs, satisfied or dissatisfied (Indrasari, 2017). Hasibuan (2010) stated that job satisfaction is an emotional attitude that is exciting and loving jobs. This definition is the same as the opinion of Syahyono (2016), that job satisfaction will arise if the employees enjoy their jobs and the environments, while dissatisfaction feeling will arise if the employees do not enjoy their jobs. The job satisfaction is a positive behavior that is felt by the employees toward their jobs which is affected by the job situation assessment (Robbins and Judge, 2012). Work situations can be one of the motivations for employees to achieve their job satisfaction within the organization. Job satisfaction is a reflection of the employee's feelings about being happy or unhappy, comfortable or uncomfortable with the work environment where the employee works (Wibowo, Musadieq, and Nurtjahjono, 2014). Ivanchevich (2014) explained that job satisfaction is everyone's behavior toward their job. The job satisfaction is generated from employees' perceptions about their jobs and the suitability level between individuals and organizations.

Organizations have to measure their members' job satisfaction to know the suitability between the individuals and the reality of the organization's duties. The Airlangga Healthcare Center, Surabaya carries out surveys to measure the employees' job satisfaction annually, and the employee's job satisfaction target is $80 \%$. The measurement of employees' job satisfaction employed the Job Descriptive Index (JDI). JDI is one of the most popular questionnaires that is used to measure job satisfaction and consists of 72 questions. The JDI measures the commonly five factors of job satisfaction, i.e., satisfaction towards job, salary, supervision, promotion, and co-worker (Tasios and Giannouli, 2017).

The frequency distribution of job satisfaction in 2011 was grouped by several aspects, i.e., aspects of job, salary, recognition, supervision, coworkers, chance to develop, and the job situation. It showed that 4 of 7 aspects of job satisfaction had not achieved, such as aspects of the salary, recognition, supervision, chance to develop. There were 3 of 7 aspects of the achieved target in job satisfaction, i.e., aspects of the job, co-workers, and job situation. Based on the data, the problems of this study were that four aspects had not achieved the organization's goals, however, 3 of 7 job 
satisfaction aspects were achieved at the Airlangga Healthcare Center in 2011.

Based on the job satisfaction problems, this study aims to identify the correlation between the organizational culture intensity and the employees' job satisfaction at the Airlangga Healthcare Center.

\section{METHOD}

This study employed a cross-sectional design. The population of the study was 23 employees of the Airlangga Healthcare Center. The substantial samples were 23 people. The study was conducted both in the Airlangga Healthcare Center campus B and campus C in May 2012. The data of this study were obtained from primary and secondary data. The primary data were obtained from closed questionnaires about organizational culture intensity and job satisfaction. The respondents consisted of doctors, nurses, administration staff, and the other staff at the Airlangga Healthcare Center. Meanwhile, the secondary data were obtained from the operating. As a result, the data were analyzed using SPSS application by employing descriptive analysis and cross-tabulation analysis between the organizational culture intensity and job satisfaction.

\section{RESULTS AND DISCUSSION}

\section{The Measurement of the Organizational Culture at the Airlangga Healthcare Center, Surabaya}

The result shows the measurement of the organizational culture intensity at the Airlangga Healthcare Center through the aspects of excellent quality service, discipline, cooperation, togetherness, and trust.

Based on Table 1, it shows that the strongest aspect of the organizational cultures is the cooperation aspect which reached $73.9 \%$. On the other hand, the organizational culture aspect that had moderate intensity was the togetherness aspect. However, the organizational culture intensity was quite high amounted to $56.5 \%$.

The result above shows that the Airlangga Healthcare Center had a strong organizational culture with a strong enough and strong organizational culture intensity as a whole. Therefore, the most influential aspect of organizational culture that supported the organizational culture intensity was cooperation. This result was the same as the research conducted by Hatta, Musnadi, and Mahdani (2017), which showed that cooperation can positively affect the members' job satisfaction. In addition, cooperation could also affect members' performances. Based on the research conducted by Panggiki, Lumanauw, and Lumintang (2017), it shows that the existence of cooperation between employees and the leader can improve the employees' performance.

Robbins (2015) explained that the organizational culture is divided into strong and weak organizational culture. The organizational culture at the Airlangga Healthcare Center was categorized as a strong organizational culture because the main value of the organization, cooperation aspect, was handled intensively and embraced by the employees. The result of this research was also supported by the explanation of Robbins (2015) about the strong culture characteristics, i.e., decreasing the level of employee resign, members' high agreement regarding what needs to be maintained and highly respected by the organization, and the existence of cohesive coaching, loyalty, and the organization's commitment. Furthermore, according to Pabundu (2010), there are some strong culture characteristics, i.e., the clarity of value and belief and the distribution of value and belief.

Table 1. The Distribution of Organizational Culture Intensity.

\begin{tabular}{lrrrrrrrr}
\hline \multirow{2}{*}{ Organizational Culture Aspects } & \multicolumn{6}{c}{ Organizational Culture Intensity } \\
\cline { 2 - 10 } & \multicolumn{2}{c}{ Weak } & \multicolumn{2}{c}{ Moderate } & \multicolumn{2}{c}{ Strong } & \multicolumn{2}{c}{ Total } \\
\cline { 2 - 10 } & $\mathbf{n}$ & $\%$ & $\mathbf{n}$ & $\%$ & $\mathbf{n}$ & $\%$ & $\mathbf{n}$ & $\%$ \\
\hline Excellent service quality & 0 & 0.0 & 11 & 47.8 & 12 & 52.2 & 23 & 100.0 \\
\hline Discipline & 0 & 0.0 & 8 & 34.8 & 15 & 65.2 & 23 & 100.0 \\
\hline Cooperation & 0 & 0.0 & 6 & 26.1 & 17 & 73.9 & 23 & 100.0 \\
\hline Togetherness & 1 & 4.3 & 17 & 73.9 & 5 & 21.7 & 23 & 100.0 \\
\hline Trust & 1 & 4.3 & 10 & 43.5 & 12 & 52.2 & 23 & 100.0 \\
\hline The whole of organizational cultures & 0 & 0.0 & 10 & 43.5 & 13 & 56.5 & 23 & 100.0 \\
\hline
\end{tabular}

The clarity of value and belief is the organization's value and belief included several matters that are agreed by the organization's members and also defined clearly. The organization's value and belief can be assessed from the slogan, motto, organizational philosophy, visions or organization goals, and the organizational principles. The clarity of value and belief is stated in the mission of Airlangga Healthcare Center with the basic value of excellent service quality, as well as the general basic value of discipline, cooperation togetherness, and trust.

The value and belief distribution are related to how many people accept and embrace the value and belief that have been determined by the organization. The distribution of organizational culture value and belief depends on how to disseminate the organizational cultures to be adopted by all members and be an inheritance that is provided by the leader to the new members. The dissemination and system of organizational culture inheritance can be carried out through orientation and providing guidance to the new members. Providing guidance to the new members is performed by the organization's leaders or seniors. The Airlangga Healthcare Center attempted to distribute the value and belief by disseminating its vision and missions to the new members. 
Meanwhile, the cultural inheritance such as discipline, cooperation, togetherness, and trust was performed by the seniors as the model to the new members. According to the discussion, it shows that the aspects of excellent service quality, discipline, cooperation, togetherness, and trust had been embraced by all employees.

Indeed, based on the distribution of organizational culture intensity, this matter was caused by cooperation as the most substantial organizational culture aspect and togetherness as the lowest aspect among the overall percentage of organizational culture aspects. Thus, the results of measurement using cross-tabulation analysis toward organizational culture intensity included cooperation, togetherness, and the overall employees' job satisfaction are shown in Table 3.

Table 2. Job Descriptive Index.

\begin{tabular}{|c|c|c|c|c|c|c|c|c|}
\hline \multirow{3}{*}{ Job Satisfaction's Aspects } & \multicolumn{8}{|c|}{ Satisfaction Level } \\
\hline & \multicolumn{2}{|c|}{ Less Satisfied } & \multicolumn{2}{|c|}{$\begin{array}{l}\text { Moderately } \\
\text { Satisfied }\end{array}$} & \multicolumn{2}{|c|}{ Very Satisfied } & \multicolumn{2}{|c|}{ Total } \\
\hline & $\mathbf{n}$ & $\%$ & $n$ & $\%$ & $\mathbf{n}$ & $\%$ & $\mathbf{n}$ & $\%$ \\
\hline Job & 0 & 0.0 & 5 & 21.7 & 18 & 78.3 & 23 & 100.0 \\
\hline Salary & 5 & 21.7 & 10 & 43.5 & 8 & 34.8 & 23 & 100.0 \\
\hline Supervision & 2 & 8.7 & 9 & 39.1 & 12 & 52.2 & 23 & 100.0 \\
\hline Promotion & 8 & 34.8 & 8 & 34.8 & 7 & 30.4 & 23 & 100.0 \\
\hline Co-worker & 0 & 0.0 & 5 & 21.7 & 18 & 78.3 & 23 & 100.0 \\
\hline Overall Job Satisfaction & 0 & 0.0 & 9 & 39.1 & 14 & 60.9 & 23 & 100.0 \\
\hline
\end{tabular}

\section{The Measurement of Job Satisfaction at the Airlangga Healthcare Center}

The measurement of employees' job satisfaction at the Airlangga Healthcare Center was carried out by using JDI based on the employees' job, salary, supervision, promotion, and co-worker aspects as presented in Table 2.

According to Table 2, it shows that job satisfaction aspects felt by the employees were the job and co-worker aspects reached $78.3 \%$. The overall respondent's job satisfaction was $60.9 \%$ or very satisfied level. According to the description, It shows that the employees enjoyed their jobs because of the way of giving interesting tasks for the employee and a chance to learn and have a responsibility to the tasks. In addition, the Airlangga Healthcare Center's employees felt fascinating with their partners because their partners worked cooperatively and they built a good relation, therefore the employee enjoyed doing their jobs (Haris, 2017).

Besides, the employees were satisfied enough with salary aspect amounted to $43.5 \%$. It showed that the employees believed that the received salary was enough in terms of the amount and fairness. The study showed that salary satisfaction affected the employees' satisfaction. Andalen and Darmastuti (2015) explained that the satisfaction of the received salary shows that someone will feel satisfied if the salary fits the expectation. If the received salary fits the expectation, the employees' job satisfaction will be very satisfied. Meanwhile, the promotion was felt less satisfied with the employees and only reached $34.8 \%$. It might happen because the promotion or chance to develop had not existed.

The job satisfaction is a positive behavior that related to the employee's adaptability toward the influencing factors, such as financial satisfaction factor, physical satisfaction factor, social satisfaction factor, and psychological satisfaction factor (Abadiyah and Purwanto, 2016).

The financial satisfaction is the factor that shows the fulfillment of employees' desires to the financial need received to fulfill their daily needs. If this factor is fulfilled, job satisfaction can be achieved. The financial factor includes the system and the salary, social guarantee, allowance, given facilities, and promotion. The research conducted by Santoso (2015) showed that financial compensation has a significant effect on employees' job satisfaction.

The physical satisfaction factor is the factor related to the physical condition, the work environment, and the employee's physic. If this factor is completed, job satisfaction can be achieved. The physical factor includes: kind of jobs, the setting of work time and breaks time, work equipment, the room temperature, lighting, air exchange, employee's health, and age. Based on the research conducted by Pangestu, Mukzam, and Ruhana (2017), physical environment factors significantly affect the employees' job satisfaction.

The social satisfaction factor is the factor related to the social interaction between the employees and others, the leaders, and other employees from different jobs. The factor includes solid colleagues, fair and wise leaders, and the fair directions and commands. According to the research of Madjid and Widiastuti (2013), the social factor has positive effects on employees' job satisfaction, therefore if social factors increase, employees' job satisfaction will also increase.

The psychological satisfaction factor is a factor related to the psychological condition of each employee. If this factor is completed, job satisfaction can be achieved. The factor includes interests, peace in work, attitudes towards work, talents, and skills. Based on the research conducted by Madjid and Widiastuti (2013), psychological factors, such as peace, effects on employees' job satisfaction. Employees will feel satisfied at work if, in reality, they feel greater than the expectation. Out of 4 factors that affect job satisfaction, the most dominant factors are jobs and solid colleagues.

\section{The effect of the Organizational Culture Intensity toward Job Satisfaction}

Based on the measurement of the organizational culture intensity, organizational culture aspects implemented at the Airlangga Healthcare Center showed that the whole organizational cultures were classified as strong organizational culture. 
According to the JDI, the oeverall employees' job satisfaction was satisfied overall. Therefore, the study analyzed the effect of the organizational culture intensity included the cooperation, togetherness, and the whole organizational culture toward the employees' job satisfaction as shown in Table 3.

According to Table 3, the organizational culture aspect of excellent service quality with the strong organizational culture intensity reached $75.0 \%$ or very satisfied compared to the strong enough organizational culture intensity with $45.5 \%$ and it showed satisfied job satisfaction. The discipline aspect with the strong organizational culture intensity reached $73.3 \%$ or very satisfied compared to the strong enough organizational culture intensity with $37.5 \%$, and it also showed satisfying job satisfaction. The cooperation aspect with the strong organizational culture intensity amounted to $70.6 \%$ or very satisfied
Doi: 10.20473/jaki.v7i2.2019.116-122

compared to the strong enough organizational culture intensity with $33.3 \%$. The togetherness aspect of weak organizational culture intensity amounted to $100 \%$ or very satisfied, while the strong organizational culture intensity reached $80.0 \%$ or very satisfied compared to the strong enough organizational culture intensity with $53.0 \%$. The trust aspect with weak organizational culture intensity reached $0 \%$ very satisfied, while the strong organizational culture intensity has the satisfied job satisfaction of $83.3 \%$ or very satisfied compared to the strong enough organizational culture intensity with $40.0 \%$. Thus, the whole organizational culture aspects with the strong organizational culture intensity reached $92.3 \%$ or very satisfied compared to the strong enough organizational culture intensity with $20.0 \%$ very satisfied.

Table 3. The effect of Organizational Culture Intensity toward the Employees' Job Satisfaction.

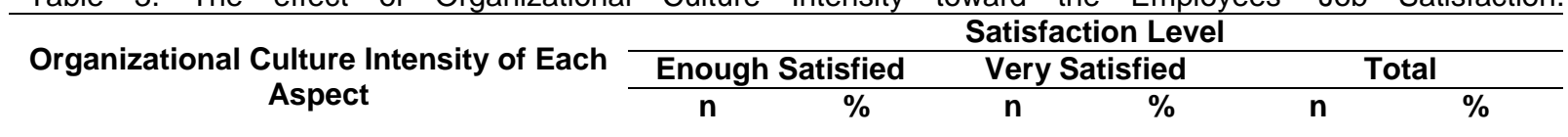

\begin{tabular}{lrrrrrr}
\hline Excellent service quality & \multicolumn{1}{l}{} & & & \\
\hline Strong Enough & 6 & 54.5 & 5 & 45.5 & 11 & 100.0 \\
\hline Strong & 3 & 25.0 & 9 & 75.0 & 12 & 100.0 \\
\hline Total & 9 & 39.1 & 14 & 60.9 & 23 & 100.0 \\
\hline
\end{tabular}

\begin{tabular}{|c|c|c|c|c|c|c|}
\hline \multicolumn{7}{|l|}{ Discipline } \\
\hline Strong Enough & 5 & 62.5 & 3 & 37.5 & 8 & 100.0 \\
\hline Strong & 4 & 26.6 & 11 & 73.3 & 15 & 100.0 \\
\hline Total & 9 & 39.1 & 14 & 60.9 & 23 & 100.0 \\
\hline \multicolumn{7}{|l|}{ Cooperation } \\
\hline Strong Enough & 4 & 66.7 & 2 & 33.3 & 6 & 100.0 \\
\hline Strong & 5 & 29.4 & 12 & 70.6 & 17 & 100.0 \\
\hline Total & 9 & 39.1 & 14 & 60.9 & 23 & 100.0 \\
\hline \multicolumn{7}{|l|}{ Togetherness } \\
\hline Weak & 0 & 0.0 & 1 & 100.0 & 1 & 100.0 \\
\hline Strong Enough & 8 & 47.0 & 9 & 53.0 & 17 & 100.0 \\
\hline Strong & 1 & 20.0 & 4 & 80.0 & 5 & 100.0 \\
\hline Total & 9 & 39.1 & 14 & 60.9 & 23 & 100.0 \\
\hline \multicolumn{7}{|l|}{ Trust } \\
\hline Weak & 1 & 100.0 & 0 & 0.0 & 1 & 100.0 \\
\hline Strong Enough & 6 & 60.0 & 4 & 40.0 & 10 & 100.0 \\
\hline Strong & 2 & 16.7 & 10 & 83.3 & 12 & 100.0 \\
\hline Total & 9 & 39.1 & 14 & 60.9 & 23 & 100.0 \\
\hline \multicolumn{7}{|c|}{ The Whole of Organizational Cultures } \\
\hline Strong Enough & 8 & 80.0 & 2 & 20.0 & 10 & 100.0 \\
\hline Strong & 1 & 7.7 & 12 & 92.3 & 13 & 100.0 \\
\hline Total & 9 & 39.1 & 14 & 60.9 & 23 & 100.0 \\
\hline
\end{tabular}

Based on the description of Table 3, trust was an organizational culture aspect with the strong organizational culture intensity that was most influential towards job satisfaction and reached
$83.3 \%$. It shows that even though cooperation was the strongest organizational culture aspect that is embraced by the employees, the trust aspect was more influential on job satisfaction. On the other 
hand, the whole organizational culture affected job satisfaction and reached $92.3 \%$. It shows that there are eight factors of the organizational culture that affected job satisfaction. Therefore, although the trust had the strongest effect on job satisfaction than the other aspects, the overall organizational culture showed that those aspects could affect job satisfaction if they were implemented simultaneously. This statement fits with the research conducted by Tumbelaka, Habsji, and Nimran (2016) that the organizational culture affects significantly to job satisfaction. This opinion supports the statement that a strong organizational culture will produce high job satisfaction and vice versa. In Addition, according to the research of Jufrizen et al., (2018), organizational culture has a significantly positive value and direct effect to job satisfaction. The research conducted by Wahyuniardi and Renaldo (2018) also stated that organizational culture affects job satisfaction significantly and directly.

According to the research conducted by Darmadi (2016), the more aspects of organizational culture fit with the employees' desire, the higher job satisfaction will be achieved. It is also related to the research conducted by Theresia et al., (2018) that the organizational culture also has a significant effect on job satisfaction that it can be imparted to the employees' performance. Based on the research conducted by Nasution, Musnadi, and Faisal (2018), the organizational culture affects the members' job satisfaction in the organization positively and significantly. The other research conducted by Mariati and Mauludin (2018) showed that the organizational culture affects positively and significantly to the employee's job satisfaction that it might achieve the organization's performance and goals well. It might improve the organizational culture intensity in order to achieve more job satisfaction. Therefore, the organizational culture had highly affected the employees' job satisfaction.

\section{CONCLUSION}

This study concludes that organizational culture intensity at the Airlangga Healthcare Center. In addition, the whole organizational culture such as the excellent service quality, discipline, cooperation, togetherness, and trust are considered as the strongest organizational culture .

However, there are two aspects of organizational culture aspects that are considered as weak organizational culture intensity by a few employees at the Airlangga Healthcare Center. Whereas among five aspects of job satisfaction, the employees feel very satisfied with the job and colleague aspects. The overall employees' job satisfaction is on a very satisfying level. However, the salary aspect is considered satisfied enough.

The organizational culture intensity, such as excellent service quality, discipline, cooperation, togetherness, and trust, is one of the factors that affect the job satisfaction because the strong organizational culture intensity reaches $92.3 \%$. It means employees feel very satisfied with their jobs and their colleagues. Thus, the more aspects of strong organizational culture intensity are adopted, the more job satisfaction will be achieved at the Airlangga Healthcare Center. This result shows that the intensity of organizational culture at the Airlangga Healthcare Center affects employees' job satisfaction.

Based on this study, it is expected that the Airlangga Healthcare Center can improve the weak aspects of organizational culture for a few employees, such as cooperation and trust. Thus, the whole organizational culture intensity will increase, and job satisfaction will increase. Further research on the current organizational condition at the Airlangga Healthcare Center should be conducted to re-measure the organizational culture and job satisfaction of employees by using different measurement methods.

\section{CONFLICT OF INTEREST}

The authors state that there is no conflict of interest for this article.

\section{REFERENCES}

Abadiyah, R. and Purwanto, D. (2016) 'Pengaruh Budaya Organisasi , Kompensasi terhadap Kepuasan Kerja dan Kinerja Pegawai Bank di Surabaya', Jurnal Bisnis, Manajemen, dan Perbankan, 2(1), pp. 49-66.

Andalen, A. and Darmastuti, I. (2015) 'Pengaruh Kepuasan Gaji, Pengembangan Karyawan, dan Dukungan Organisasional terhadap Turnover Intention (Studi pada Karyawan PT. Asuransi Tokio Marine Indonesia)', Diponegoro Journal of Management, 4(4), pp. $1-13$.

Darmadi (2016) 'Pengaruh Budaya Organisasi dan Iklim Organisasi terhadap Kepuasan Kerja dan Dampaknya terhadap Kinerja Pegawai di Yayasan Tenaga Kerja Indonesia', Jurnal Eksekutif, 13(2), pp. 264-285.

Hakim, A. and Hadipapo, A. (2015) 'Peran Kepemimpinan dan Budaya Organisasi terhadap Kinerja Sumber Daya Manusia di Wawotobi', Ekobis, 16(1), pp. 1-11.

Haris, H. (2017) 'Pengaruh Kepuasan Kerja dan Komitmen Organisasi terhadap Kualitas Layanan di PT. Asuransi Jasindo (Persero) Kantor Cabang Korporasi dan Ritel Bandung', Jurnal Ekonomi Manajemen Sumber Daya, 19(2), pp. 135-151. doi: 10.23917/dayasaing.v19i2.5513.

Hasibuan, M. S. P. (2010) Manajemen Sumber Daya Manusia. Jakarta: Bumi Aksara.

Hasibuan, M. S. P. (2011) Manajemen: Dasar, Pengertian, dan Masalah. Jakarta: Bumi Aksara.

Hatta, M., Musnadi, S. and Mahdani (2017) 'Pengaruh Gaya Kepemimpinan, Kerjasama Tim dan Kompensasi terhadap Kepuasan Kerja serta Dampaknya pada Kinerja Karyawan PT. PLN (Persero) Wilayah Aceh', Jurnal Magister Manajemen Fakultas Ekonomi dan Bisnis Unsyiah, 1(1), pp. 7080.

Indrasari, M. (2017) Kepuasan Kerja dan Kinerja Karyawan Kepuasan Kerja dan Kinerja 
Karyawan Tinjauan dari Dimensi Iklim Organisasi. 1st edn. Sidoarjo: Indomedia Pustaka.

Ivanchevich, J. M. (2014) Organizational Behavior and Management. 10th edn. London: Sage Publications.

Jufrizen et al. (2018) 'The Effect of Organizational Culture and Islamic Work Ethic on Permanent Lecturers' Job Satisfaction, Organizational Commitment and Work Performance at Private Islamic Universities in the City of Medan', in 1st International Conference of Economic Studies (ICOES) 2018. Pematang Siantar, pp. 179-186.

Madjid, A. and Widiastuti, T. (2013) 'Faktor-faktor yang Mempengaruhi Kepuasan Kerja Karyawan di PT. Intrias Mandiri Sejati (IMS)', Jurnal Aset, 15(2), pp. 71-80.

Mariati and Mauludin, H. (2018) 'The effect of Organizational Culture and Work Motivation on Employee Performance, Job Satisfaction as Intervening Variable (Study on Secretariat Staff of Pasuruan Regency)', IOSR Journal of Business and Management, 20(8), pp. 3039. doi: 10.9790/487X-2008013039.

Nasution, E. H., Musnadi, S. and Faisal (2018) 'Faktor-Faktor yang Mempengaruhi Kepuasan Kerja dan Dampaknya terhadap Kinerja Pegawai Kanwil Direktorat Jendral Kekayaan Negara Aceh', Jurnal Magister Manajemen, 2(1), pp. 123-134.

Novita, Sunuharjo, B. S. and Ruhana, I. (2016) 'Pengaruh Kepuasan Kerja dan Komitmen Organisasional terhadap Kinerja Karyawan (Studi pada PT. Telekomunikasi Indonesia, Tbk Witel Jatim Selatan, Malang)', Jurnal Administrasi Bisnis, 34(1), pp. 38-46.

Pabundu, T. (2010) Budaya Organisasi dan Peningkatan Kinerja Perusahaan. 3rd edn. Jakarta: Bumi Aksara.

Pangestu, Z. S. D., Mukzam, M. D. and Ruhana, I. (2017) 'Pengaruh Lingkungan Kerja terhadap Kepuasan Kerja (Studi pada Karyawan Perum Perhutani Ngawi)', Jurnal Administrasi Bisnis, 43(1), pp. 157-162.

Panggiki, A. C., Lumanauw, B. and Lumintang, G. G. (2017) 'Pengaruh Kompensasi, Kerjasama Tim, dan Kepuasan Kerja terhadap Kinerja Karyawan pada AJB Bumiputera 1912 Cabang SAM Ratulangi',
Jurnal Riset, Ekonomi, Manajemen, Bisnis, dan Akuntansi, 5(2), pp. 3018-3027.

Robbins, S. P. (2015) Organizational Behavior: Concepts, Controversies, Applications. 7th edn. Jakarta: Pearson Indonesia.

Robbins, S. P. and Judge, T. A. (2012) Perilaku Organisasi. 2nd edn. Jakarta: Salemba Empat.

Santoso, D. O. (2015) 'Pengaruh Kompensasi Finansial dan Non Finansial terhadap Kepuasan Kerja Karyawan Akor Global', Jurnal AGORA, 3(1), pp. 56-61.

Schein, E. H. (2016) Organizational Culture and Leadership. 5th edn. San Francisco: Jossey Bass.

Syahyono (2016) 'Analisis Pengaruh Situasi Kerja , Kepuasan Kerja dan Motivasi Kerja terhadap Kinerja', Jurnal Administrasi dan Kebijakan Publik, 6(2), pp. 52-72.

Tasios, T. and Giannouli, V. (2017) 'Job Descriptive Index (JDI): Reliability and Validity Study in Greece', Archives of Assessment Psychology, 7(1), pp. 61-91.

Theresia, L. et al. (2018) 'The effect of Culture, Job Satisfaction and Motivation on the Performance Lecturer/Employees', in International Conference on Industrial Engineering and Operations Management. Bandung, pp. 2541-2552.

Tumbelaka, S. S. X., Habsji, T. Al and Nimran, U. (2016) 'Pengaruh Budaya Organisasi terhadap Kepuasan Kerja, Komitmen organisasional dan Intention to Leave (Studi pada Karyawan PT. Bitung Mina Utama)', Jurnal Bisnis dan Manajemen, 3(1), pp. 94108.

Wahyuniardi, R. and Renaldo, H. N. (2018) 'Pengaruh Kepemimpinan Transformasional dan Budaya Organisasi terhadap Kepuasan Kerja serta Dampaknya pada Kinerja Karyawan', Jurnal Teknik Industri, 19(2), pp. 118-126.

doi: 10.22219/JTIUMM.Vol19.No2.108-126.

Wibowo, M., Musadieq, M. Al and Nurtjahjono, G. E. (2014) 'Pengaruh Lingkungan Kerja terhadap Kepuasan Kerja Karyawan (Studi pada Karyawan PT. Telekomunikasi Indonesia Tbk. Kandatel Malang)', Jurnal Administrasi Bisnis, $\quad$ 16(1), $\quad$ pp. 1-9. 